\title{
Rethinking Development in Tonga: Dialogues with Sefita Hao'uli, Kalafi Moala, and Melino Maka
}
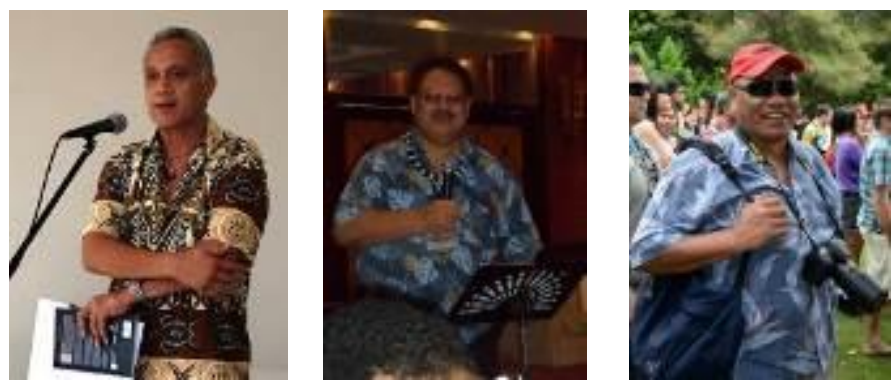

\begin{abstract}
Acknowledging the work of the late Tongan professors, Futa Helu and Epeli Hau'ofa, this is the first in a series of four articles. Teena Brown Pulu revisits Helu's criticism of development in Tonga by framing interview conversations with Sefita Hao'uli, Kalafi Moala and Melino Maka in a Hau'ofastyled narrative that draws on satire and tongue-in-cheek prodding as a form of criticism. This is Tongan storytelling with a critical edge which will leave the reader much clearer about the convoluted circumstances and unpredictable politics driving development and democracy in the Kingdom of Tonga.
\end{abstract}

\section{Prelude to the text}

What on earth has moa'uli, literally translated as black chicken, got to do with Tongan relationship management? English language references to the millennium development

Teena Brown Pulu has a PhD in anthropology from the University of Waikato. She is a senior lecturer in Pacific development at AUT University. Her first book was published in 2011, Shoot the Messenger: The report on the Nuku'alofa reconstruction project and why the Government of Tonga dumped it. 
goals and small island developing states form a global index which aid donors use to deal with South Pacific Natives combating borderline poverty, dying from non-communicable diseases, and sinking in climate change. But in the Tongan development phrasebook there is a black chicken. Are you serious? And if I am a development anthropologist and a Tongan academic employed in a New Zealand university then why have I not come across this dark coloured fowl?

In the Auckland spring of 2013 I initiated a series of development conversations with community leaders, three men who were born and raised in the Kingdom of Tonga. Radio broadcaster Sefita Hao'uli, journalist Kalafi Moala, and Tongan advisory council chair Melino Maka were not newcomers to debating issues of public concern and disseminating their opinions through media. If anything, their media savviness made them household names among Tongan people in the homeland and overseas diaspora. I came from another type of media - academia - and I was a woman who brought these three men together to talk in a group so I could publish the insights learned from their dialogues, strategies and approaches to doing development by a Tongan way of thinking.

There was a specific knot I wanted to unravel, which was first noted in an essay by the late Futa Helu (Helu, 1999). Helu's writing epitomised the Tongan "organic intellectual," as Gramsci coined the term (Gramsci, 2005). By this, I mean he blended lived experience and an intuitive understanding of his political surroundings with a learned application and critique of academic theory. Put simply, Helu argued that Tongan development was unsound and prone to failure because the state and political leaders put the cart before the horse. Tonga had imported a cart of Western development models, ideas, and values without critically thinking how a foreign system of economic growth and profit-making might fit, or not, with the existing culture and power structure.

Tonga suffered from development depression seeing consecutive governments put many carts before horses causing little forward movement for the population as a whole. A privileged few made financial gains from the imported development carts but they were the ruling class, an educated middle class, along with New Zealand, Australian and Chinese immigrants, combining forces to dominate the business sector while ejecting small Tongan entrepreneurs to the peripheral poorhouse. These social groups had power and resources to 
begin with and the truth was development and democracy entrenched the status quo. But it did not, and was not by any means designed to challenge the stronghold of wealth for fairer redistribution and to make room for others with less.

If there was a way to put the horse before the cart then how would development in Tonga take place? What would a Tongan horse look like not to mention a black chicken, and why would Tongan horses and black chickens facilitate the cart's movement and direction when development is an ubiquitous concept adopted by developing countries to integrate them into a world system of economy? As Kalafi Moala inquired, what is actually in the cart and how do we know it is useful to helping Tonga's commoner class, the country's majority? (Moala, 2013a; Hau'ofa, 2008).

This first essay of four stimulated by talks with Sefita Hao'uli, Kalafi Moala, and Melino Maka unearths Tonga's development contradictions and piecemeal solutions. It probes the awkward and often unwanted presence of Tongans born overseas in Tonga's development. Are Tonga's descendants born offshore included in island affairs? If not, then why not considering that remittances sent by kinfolk abroad generate a third of the country's gross domestic product, and numbers in the New Zealand, Australian, and USA diaspora are growing at a faster rate to those living in Tonga, eclipsing the homeland population.

Succinctly, what political conditions cook up the same old development troubles topped with haphazard, half pie remedies? What becomes clear is that tangled in global development language as we unquestioningly ingest it, lies the collective sense-making of others, the counter narratives of small society peoples who not only understand the systematic roadblocks to getting to development done in their island homelands, but are painfully aware of how power and subjugation prevents them from doing development their way, a way that advances the people without power (Foucault, 1982).

\section{Contested truth}




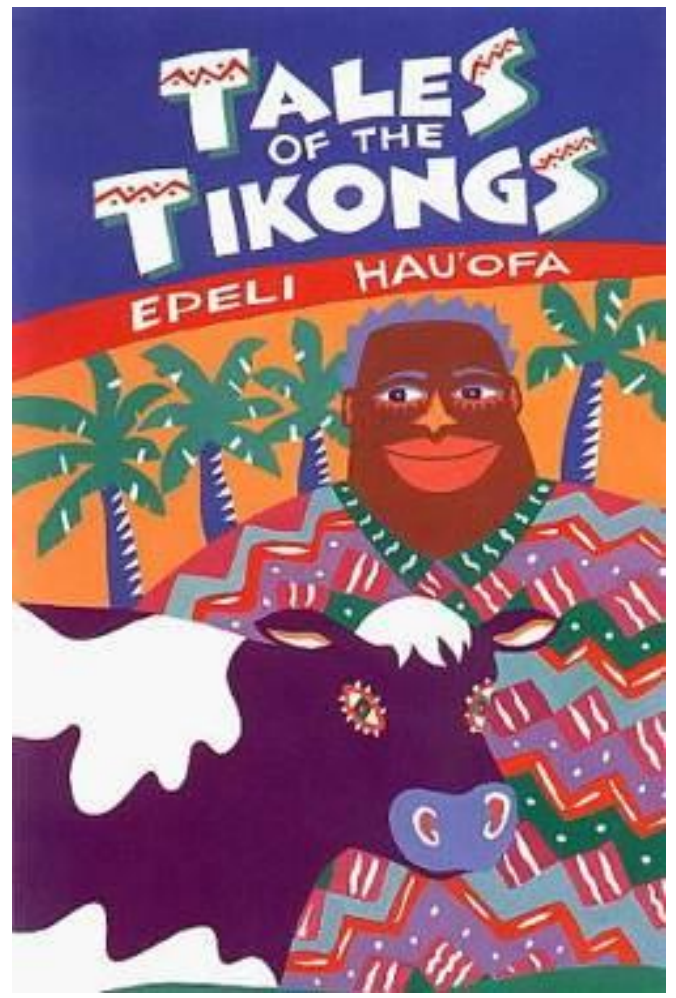

Those who believe that truth, like beauty, is straight and narrow should not visit our country or they will be led up the garden path or sold down the river (so to speak, since we have no rivers). Truth is flexible and can be bent this way so and that way so; it can be stood on its head, be hidden in a box, and be sat upon. Only Manu treads the straight and narrow path, followed by no one because that path exists entirely in his head. Most real roads on our island are very narrow, very crooked, and full of pot holes. Here no second-hand bus from Suva lasts more than six months. There are a few straight roads with pot holes, but they are all in the bush where they serve no good purpose. (Hau'ofa, 1994, p. 8). 
"That is not the truth of it!" Snapping at Kalafi Moala, I almost spat out my coffee in the cafeteria at AUT Manukau on a Friday September morning. "But in Tonga, the truth is in percentages and fractions," he responded, grinning from earto-ear (Moala, 2013a). Kalafi pulled his verse straight from Epeli Hau'ofa's Tale of the Tikongs (1994), and in that fleeting moment I felt like the book's main character, Manu. Similar to Manu from the island of Tikong I could see myself clasping to a "straight and narrow" interpretation of the truth which existed entirely in my head, inside my anthropologist brain that stored English language texts chock-full with white people's descriptions of South Seas Natives (Hau'ofa, 1994, p. 8). The lazy native, the lying native, the confused native, the mischief-maker native were racial tropes that sprang to mind (Teaiwa, 1995; Alatas, 2012; Brown Pulu, 2013a).

It is hard to unlearn colonisation and separate out the part of my brain disciplined to think like an English speaking woman, a Western educated woman with brown skin traced to my Tongan origins and the citizenship and mixed-blood of a developed country. The other part of me stirs a deeper consciousness of power, the Tongan portion that sees power executed. I do not speak a Native tongue with the same level of proficiency as English. Instead, I read with my eyes what people are saying and not saying because social control prevents them from having their say. Surreptitiously I know that I write from a position without power by narrating my own truth in contemporary Tongan society (Said, 1978, 2000). Intuitively I feel that I will get into trouble by talking back to the centre from the periphery (Spivak, 1990).

But I do it anyway because I can and need to; for there is little purpose in claiming to be a critic if my fear of reckoning prevents me from undertaking a role as society's conscience. Under these political conditions, it is understandable that only madly brave, impassioned, and tortured souls wilfully make themselves vulnerable. They do this by thinking, writing, and performing "dangerous words," daring thoughts, and dauntless deeds in a small, cosseted, class-structured, island Kingdom (Brenneis and Myers, 1984). And there are too few of us.

My lingering dread is that research on Tonga produced by Tongans has become insipid reporting reflective of popular development parables regurgitated by the state, the state's donors, the state's bankers, the state's custodians, all responsible for keeping small island governments 
downtrodden, dependent, and desperate for artificial lifesupport systems. The disquiet crouching inside my chest urged that I exchange ideas about development and what it meant in practice to ordinary Tongans on the receiving end of its influence with Sefita Hao'uli, Kalafi Moala and Melino Maka; men who at one level make their livelihoods from the development industry as consultants and independent business entrepreneurs, but who are also seen in public life as grassroots activists and political agitators lobbying the Tongan state for change on behalf of the people.

The double-bind is that a small island developing state is in fact a cut-throat aid industry propelling people to rival for scarce employment openings as consultants, contractors, and specialist advisors in a donor-driven economy. Development rears dependency over sustainability. In this political climate, local Tongans complain about consultants bankrolled by aid donors in tow with the Tongan state. They feel that cash which could be used for implementing projects is diverted to consultants for advice. The slippery question resurfacing time and again is does a poor country like Tonga with a small population need an overpaid tribe of advisors? And when advisors are paid more than senior bureaucrats, legislators, and ministerial decision-makers on the national executive does that mean they have more sway over the country's development? The argument is the development gravy train reproduces more consultants, and by doing so increases their power and creates further jobs for them not us because white New Zealanders and Australians alongside the odd Tongan educated or based in these countries are the preferred kind. Who decides what kind is allowed to direct development - the donor, the banker, or the state? (Johnson, 2013).

Furthermore, as Michel Foucault wrote, the very execution of power turns human beings into subjects (Foucault, 1982), which for myself means that I am the subject of my own research and writing. Faced with this situation, the way I process thought on my other side is grafted delicately to a Tongan emotion-scape. Consequently, I get overly sensitive about my kinship attachment to the Kingdom of Tonga. I can also turn vigilantly territorial about Tonga by claiming this is my research terrain and I have just as much right to be here as full-blooded Tongans, and even more right to be here than white people and foreigners.

Such polemics and poetics that make it complexly problematic to be half-cast were playing out in real life 
conversation. Here I was "carved and halved" while talking to Kalafi Moala, not knowing that the emotional insecurity and feeling out-of-place switch would get flicked on high but understanding that when it does, my mood turns tetchy and my mouth sharpens up emitting words that cut, chop, and censure (Marsh, 2009).

On reflection, I can understand why full-blooded Tongans consider me a hard critic for a woman. Although in my own eyes, I see that my writing about Tonga propels me to confront situations where I have to put up or shut up. My preference has been to put up a fight. It is my way of showing that I have the courage and integrity to stand by my research, to stand up for the written word I have committed to paper and publication, rather than submissively lower my head and fie vale loi; that is, to pretend I do not know there are volatile tensions seething, simmering, and spluttering beneath the surface of Tongan politics and society.

\section{Punishing the "plastics"}

"Our lives begin to end the day we become silent about things that matter" (King, 1986). 'Ofa Guttenbeil-Likiliki posted this excerpt on my Facebook page (Guttenbeil-Likiliki, 2013a). Taken from a speech given by Martin Luther King Jnr, I felt heartened that she saw the sentiment was somehow befitting to me. I had grown accustomed to Tongan women gesturing support and acceptance wrapped in affirming words, especially professional women working as educators, leaders of nongovernment organisations, and human rights campaigners for women and children. But there was a gender twist to the story as the opposite scenario played out with Tongan men of similar social standing, professional men who claimed the territory and title of educators and community activists. ${ }^{1}$ Who they were advocating for and whether any public good emanated from their thoughts, I often queried.

Amazing plastics sticking together. Just catching up with the goss [gossip] of the colonised. Very predictable small mindedness. [Facebook 1, 2013].

The writer is a university professor, an older Tongan male who migrated to New Zealand for employment. He wrote on my Facebook page, deliberately. He wanted to impress on me, specifically, that in his mind I am the ringleader of the "plastics," the Tongan women (more so than men) born and 
raised in New Zealand with higher degrees who research and publish about Tonga and Tongans in New Zealand. "Plastics" is a derogative slur meaning that $\mathrm{I}$ am accused of being culturally inauthentic, a fake replica of a real Tongan born and raised in Tonga like him.

As an insult, he intended to dress-me-down in two mutually related ways. The inception of "plastics" is an allusion to mixed-race and the increasing number of Pacific Islanders born in the New Zealand, Australian, and USA diaspora of multiple ethnicity, particularly the blend of Native Pacific Islander and European ancestry. Historically the colonial trope was half-cast, a term that has persisted in Pacific Island homelands and the overseas diaspora to label social change caused by identity complexity. In this context, "plastics" is a simplistic reference to mixed-blood inferring impurity and cross-cultural contamination. The view is that inheritors of the social condition are taken as defiled because the mixing up of different races causes hybridity, the manufacturing a synthetic culture and identity.

Second, "plastics" is also a term implying the "accident of birth" (Spivak, 1990, p. 99) triggers the root cause of social disorder. To be born outside of Tonga produces a culturally pessimistic result because it means that one is misplaced from, and has missed out on, the origin birthplace and is furthermore misguided to claim an equivalent cultural class and category to authentic Tongans from Tonga. In short, the outsider can never be counted on equal footing with the real Tongans from inside the homeland. These types suffer cultural confusion constructing complicated identities - a tangled mess of bits-and-pieces from all over the place - that deviate from the orthodoxy of one location in Tonga.

Karlo Mila-Schaaf, a sociologist of Tongan and Pakeha (white/European New Zealander) descent gave this identity classification a "tongue-in-cheek" name calling it the "New Zealand-born identity crisis" (Mila-Schaaf, 2013, p. 49).

The tongue-in-cheek phrase New Zealand-born identity crisis is obviously not a serious clinical diagnosis, but it could be described as a community prognosis. It may be invoked in disapproval, or said in jest to tease, or sometimes used simply to verbalise the complicated circumstances in which New Zealand-born people of Pacific descent must construct their identities and operate culturally. (Mila-Schaaf, 2013, p. 49). 
The catch in Mila-Schaaf's tale is that the traditionalists of Pacific Islander communities in New Zealand, who are predominantly migrants, can be fundamentalist faultfinders forecasting the fate of "New Zealand-born people of Pacific descent" as an identity disaster (Mila-Schaaf, 2013, p. 49). What interests me is how, and in what social and political situations, do Tongan migrants to New Zealand breach cultural conformity by stepping outside the role of criticising New Zealand born Tongans for not being an exact replica of people born and raised in the homeland? When does tolerance and acceptance of the difference and disjuncture between homeland Tongans and their overseas born counterparts prevail, and under what circumstances of dialogical exchange?

Name calling aside, why use my Facebook wall as the social site to scrawl insults? Why did the writer not update their own Facebook status by listing me and others he referred to as Tongan "plastics" on his wall? Entering another's territory and instant gratification are one set of drivers that research about Facebook has noted (Kaplan and Haenlein, 2010; Quan-Haase and Young, 2010). As Australian anthropologist Helen Morton Lee commented, internet forums "provide Tongans overseas with a ... chance to discuss issues and air their opinions" (Morton Lee, 2003, p. 8).

But social media is not singly a communication tool manoeuvred by the younger generation of "Tongans overseas" to criticise "their elders or the Tongan way" as Morton Lee described (Morton Lee, 2003, p. 9). Conversely, it is a hightech and far-reaching mode of transmission allowing culturally conservative Tongan migrants of an older generation to police the borders of who, from the overseas born brood, is criticising "their elders or the Tongan way." In turn, nonconformists and dissidents can be disciplined and punished over the internet with a ticking-off (Morton Lee 2003, p. 9).

The Kava Bowl forum and similar sites provide Tongans overseas with a means of communicating with others like themselves throughout the world and a chance to discuss issues and air their opinions in a context that, because of its computer-mediated character, seems safe and somewhat impersonal. ...When I first came across the Kava Bowl I was astonished at how openly critical were many of the posts, particularly those by young Tongans, who in 
"real life" ideally should be respectful, obedient, and never critical of their elders or the Tongan way. (Morton Lee, 2003, pp. 8-9).

Morton Lee's analysis is flawed in her self-confessed amazement "at how openly critical many of the posts ... by young Tongans" were. She believes that "in real life" the entire overseas born population of Tongans "ideally should be respectful, obedient, and never critical of their elders or the Tongan way" (Morton Lee, 2003, pp. 8-9). This is simply not true but reflects a romanticised fantasy that exists in the author's imagination. Tongans worldwide are by no means a robotic, pre-programmed, homogeneous species of human life, and nor should such an out-of-date misrepresentation be the rationale behind a white Australian anthropologist's book about a people in the 21 st century who are not her own.

What I am saying is that it is unreasonable for an outsider to assume they can capture and contain Tongans overseas by describing their essential elements to white readership as if Tongan people, the people to whom I trace my ancestry, are part of a development experiment that can be gazed at, recorded, and compared to others of non-Western, colouredskin, Third World origins (Hyndman, 2000). If anything, Morton Lee's ethnographic description is guilty of freezing an image of culture and identity according to how the power of Western thought works others over, speaks over them by cancelling out their original voice, rather than allowing "young Tongans" to speak of intergeneration change on their own terms (Said, 1978; Fordham, 1996).

Marina Alefosio, a spoken word poet representing Rising Voices and the South Auckland Poets Collective slammed this autobiographical piece in the microphone at TEDx Auckland (TEDx Auckland, 2013). ${ }^{2}$

This is me being me, I don't understand what I'm doing wrong

I crawled back to Samoa, the land I only met when I was 23 years old

When I put on my ia lavalava, sei

Lipstick curves on my cheek to make me blush a little more

And I asked for my father, "O ga Seve?"

And got laughed at by my grandmother

This is my effort to try and catch up with you Samoa 
We dine at the table all the time when I put too much masima in my food

And I still get those salty looks

I celebrate you, every other day when I let my hair down

And I get told to put the inheritance back up

We look like each other Samoa but we think like an ocean apart

Why does it always feel like I'm trying when I dance for you Samoa?

Why does it feel so natural and effortless when I nod my head to a tribe called quest

There's a reason why my hands and feet, they move forward

And not sideways

Samoa sits silently

He knows my beef is not with him

He's just fascinated to see who his people have become

See I know why you associate me with this African American culture

It is the only reference point you have for people like me

But you don't know anything about me

I call myself an 80s baby of black Polynesia

The product of migration

First generation Polynesian panther-ed racism, interrogation

The minority in the classroom

The outcast

Bunga

Coconut

Trying to find identity in something tangible

Something accessible

Something with universal appeal

You see this attitude

This buzz

This cypher

This attire

This recollection of rap songs

This video clips

This is what I love

This is what I know

And this - this is all me

Marina Alefosio 




Marina Alefosio performing her original poem 'Black Polynesia' at TEDx Auckland, Aotea Centre in August of 2013 (Photograph by TEDx Auckland, 2013)

Born in New Zealand to Samoan migrant parents, Alefosio's message is woven throughout the identity fabric of New Zealand born Tongans under 25 years old, the largest age group from the New Zealand Tongan population. By this I mean that the lived experiences and situated identities of New Zealand born Samoans and Tongans occupy a similar position in the country's racial hierarchy.

Understandably the state categorisation New Zealand Pacific people has become a politicised signpost useful for herding this critical mass and in turn, mobilising diverse peoples towards a common cause. The New Zealand location signified in New Zealand Pacific people gives scope for Samoans and Tongans born in New Zealand to stake out their identity difference to that of their migrant forebears as well as emphasise the growing up Pacific in New Zealand experience.

In a nut shell, what is the crux of common experience that essentialises growing up Pacific in New Zealand? Young New Zealanders of Pacific descent like poet Marina Alefosio name racism as the cultural identity marker they know, understand, are subjugated by, and have experienced expressly in the classroom and the education system. What does this tell 
parents and communities when young Pacific Islanders indicate racism is institutionalised and indoctrinated in educators and curricula to operate as the habitual, unquestioning, day-to-day culture of New Zealand?

Explicitly, why is racism a dirty word that migrant Tongans hold down, choke on, and have difficulty bringing up, naming, and scrutinising closely to discuss its ill-effect in public life? Concomitant to this, why is the internal discrimination of racial purity exemplified when full-blooded Tongans chastise half-casts and the New Zealand born cohort for being "plastics" not critically opened up with a scalpel and fully examined for what it is? "Racism spoken from the mouths of my own blood," said afakasi (half-cast) poet Grace Taylor (Taylor, 2011).

\section{Full-blooded affairs}

This Friday morning in September 2013 was slightly different. I could exhale some of my half-cast guilt about privilege, the kind that believes I belong to a class of educated and socially mobile Tongan-hybrids that are not as common as the regular Tongan commoner, and have my own place at the talk table. Even if my name-tag read Manu, a fictional character from Epeli Hau'ofa's Tales of the Tikongs who in real life was a Western educated and part-Tongan woman born in New Zealand with straight-laced development theories that are dreamlike, over-idealised, and somewhat illusory, at least space had been made for me to speak my mind frankly.

And that was rare. For seated in front of me for development talk over morning tea on Friday the 27th of September 2013 were three Tongan men, all older migrant men who were senior community leaders accomplished in their fields of work. How were they different to the conventional identity mould they were associated with as Tongan migrant men from an older generation that resettled overseas in the 1960s and 1970s?

To begin with, Sefita Hao'uli and Melino Maka had married Pakeha (white/European) New Zealanders. Their children were New Zealanders of Tongan and Pakeha descent which was the classic interpretation of the Native-European half-cast transplanted from Europe to its former colonies as a measurement of blood quantum and the dilution of racial purity. Sefita and Melino were accustomed to a younger generation like me, people of mixed-blood and if anything, had a high level of acceptance towards identity complexity because 
it was a standard condition for their children and living environments.

In Kalafi Moala's case, as a school leaver from Tonga High School he migrated overseas and spent the first twenty years of his adult life as a Christian missionary. His confidence and competency in multicultural situations where he was expected to tolerate, respect, and relate to people of multiple ethnic, cultural, and language backgrounds was groomed throughout two decades of working in diverse countries across Asia, the Pacific Islands, and the United States. Recently he returned to missionary work in Auckland, mentoring a younger generation of New Zealand born Pacific missionaries for overseas placement in developing South East Asian and South American countries.

Sefita, Melino, and Kalafi were an exception to the identity rule as it is no national security secret that full-blooded Tongan men born, raised and socialised in Tonga do not consent to identity space-sharing arrangements with mixedblood women, women from the younger generation who were born overseas and speak English as a first language, hybrid women who in a patriarchal island society are subordinate to men and lower in cultural value than full-blooded women. My value to Tongan society in the homeland is measured by Palangi status, meaning white people's prestige, education, speech, manner, and dollar value. This suggests a New Zealand middle-class income allowing me to be a benefactor to the remittance economy is the customary principle of my Tongan-hybrid identity. Coupled with the ability to perform my half-cast function of Western thinking, speech, and behaviour, this is my place in Tongan society. 


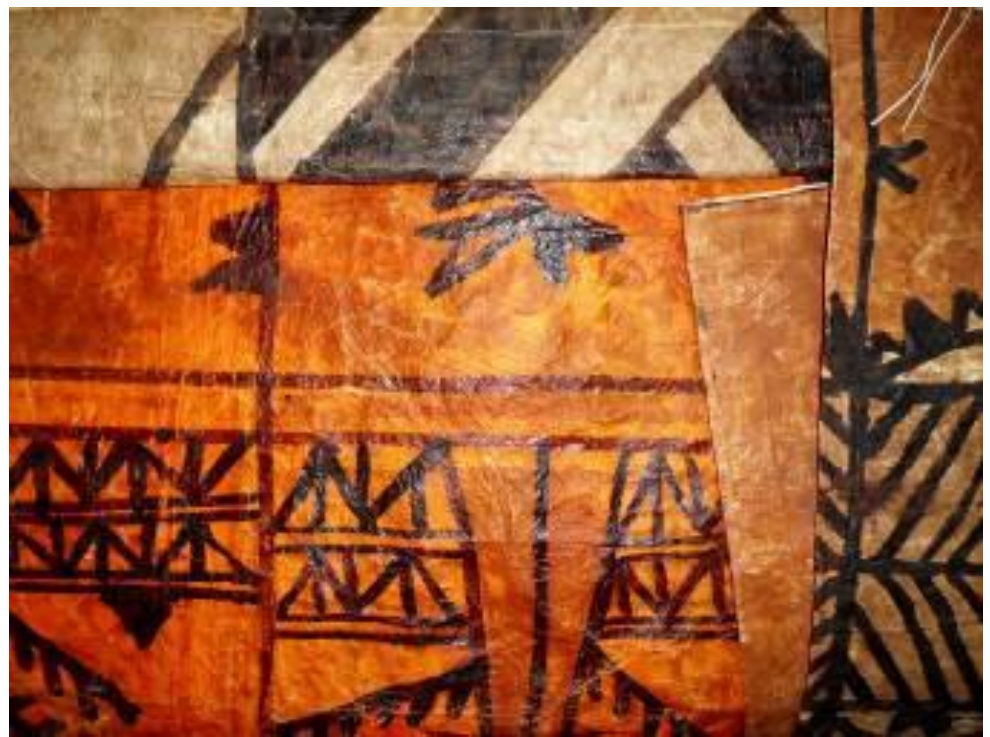

Tongan ngatu (bark cloth) used as a form of traditional wealth with kupesi (patterns) unique to Tongan art.

I have no cultural use in "full-blooded affairs" (Taylor, 2013), nor do I have any desire to be involved in traditional Tongan culture. Conservative culture including church doctrine does not fit me, especially since I am considered a proper half-cast tracing my ancestral roots to Tonga through a British male trader. "Shut up! Afakasi has no right to speak on these full-blooded affairs" wrote afakasi (half-cast) Samoan/English poet Grace Taylor (Taylor, 2013), a New Zealand citizen born and raised in South Auckland. Generally, Taylor's exclamation captures a "predicament of culture" for the European half-cast families of Tonga (Clifford, 1988).

It was French philosopher Michel Foucault who emphasised that being social beings shaped and moulded by human-made culture means that we are never truly free to say what we want, when we want, and to whom we want (Foucault, 1972). There are rules and exclusions influencing what can and what cannot be exchanged, revealed, and made known between people. Understandably then, who one is speaking to and their position of power and authority in relation to oneself defines the nature and purpose of talk. 
None so much as the Kingdom of Tonga where public dialogue between people is ranked, rated, and regimented in respect to the "order of things" (Foucault, 1970), which is, according to the status and importance of the speakers.

\section{Free speech and cultural constraint}

Hard at work in Tonga are heavier rules for people of highranking status censuring free, frank, and open exchanges of opinion. Greater restraint is therefore applied to the ruling class to ensure a protocol of niceties guides their conversation. In polite society, protocol is governed by respectful, tactful, discreet language. This type of speech signifies how power relations exercise social control. Foremost, for speakers from important class groups - the monarchy and the nobility - who are allies and collaborators, reserved communication symbolises respect for the hierarchy. Conversely, for relations that are strained and stressed, formality between speakers preserves composure, contains tension, and minimises the risk of putting your foot in your mouth, stepping out of line, and breaking rank in the hierarchy (Marcus, 1980).

My point is upholding class structure hinges on maintaining order within the classes, which for the upper echelon of society means conveying to the masses that there is no internal dissent or discord among their kind. Even if there was, the social code directing speech and behaviour would strongly disapprove of airing disagreement outside an elite circle closed-off to commoners.

What I am intimating around is Michelle Foucault's study of discourse as a system of representations conveyed through language and associated behaviour in the context in which speech and communication transacted between peoples is governed by proscriptions and prescriptions (Foucault, 1970, 1972, 1982). My inquiry intersects with Foucault by asking what social and political conditions elicit "language modification" between Tongans who represent different generation and gender groups. (Foucault, 1970, p. 256). How do we move beyond the social box that captures and positions us in the hierarchy, the very classification which confines and defines what one's kind can say to whom and how you are permitted to say it?

On this point, Foucault observed that language and behaviour is transformed "if ideas, things, knowledge or feelings ... change" (Foucault, 1970, p. 256). 
As long as language was defined as discourse, it could have no other history than that of its representations: if ideas, things, knowledge, or feelings happened to change, then and only then did a given language undergo modification, and in exactly the same proportion as the changes in question. (Foucault, 1970, p. 256).

When looking at Tonga's class-structured speech through Foucault's frame, behaviour is not transformed among the monarchy and nobility because the rules, tastes, and canons do not allow for change, nor is modification encouraged. Moreover, there are few "ideas, things, knowledge, or feelings" that surpass convention to speed up any kind of deviation to the rules (Foucault, 1970, p. 256). Comprehensibly then, this is one of the rare instances in Tonga's modern history where change has come from below, from the people positioned outside the ruling class. This has occurred because education and financial mobility has created a middle-class who prioritise in professional employment speech rules that subsequently contest the class-defined custom of not speaking back to traditional power and authority (James, 2003; Brown Pulu, 2013b).

It is here that Kalafi Moala was ahead of his time writing over a decade ago before Tonga's 2010 political reform had sought to democratise state and society. Moala explained how the conflict between culture and social change arrested and stifled his profession (Moala, 2002, p. 237).

We learned to be faithful to the tenets of our profession, but the temptation was always there to succumb to the familial, tribal, territorial, and other social ties demanding cultural and customary conformity. Whenever our commitment to journalistic principles conflicted with the demands of cultural obligations, we turned our backs on culture. Over the years we often copped our share of accusations for being culturally insensitive. People generally backed our stance when we sacrificed cultural etiquette for the sake of informing them. (Moala, 2002, p. 237).

Speaking about Tonga's media and communication industry where Moala is an established journalist, editor, and independent news outlet owner of over twenty years, he goes 
on to distinguish between working as a local reporter in contrast to a foreign one, particularly a Palangi (white/European) from overseas (Pacific Media Assistance Scheme, 2013a, 2013b). Clearly foreign journalists from Western developed countries are not constrained by the same social rules of "etiquette" and "conformity" that bind Tongan reporters to culture (Moala, 2002, p. 237). Contrariwise, Tongans are accused of operating beyond their social confinement and behaving in a "culturally insensitive," insubordinate manner if they question power as well as speak and write about contentious affairs that bluntly challenge the status quo (Moala, 2002, p. 237).

As Tongan journalists working within our own culture, we often faced challenges our foreign-born colleagues working in Tonga did not have to cope with. They were not subjected to the closed social and cultural environment Tongan journalists had to overcome. Similar situations existed in other small island nations such as Fiji, Samoa and the Cook Islands. (Moala, 2002, p. 237).

Even in the wake of this post-2010 democratisation period where state and society were upgrading their system to bring about political alignment with the ways in which Western developed countries governed the people, the common people were not free to speak publicly, nor did they publish freely. Criticising the country's rulers and political leaders, condemning their decision-making power over the masses, interrogating the strategic direction in which the Tongan government aligned itself with China, was toned-down, sidelined, and suppressed. Government owned media overruled the airwaves, discolouring the independent news outlets by reporting on state defamation cases against Kale'a, the political rag of the pro-democracy movement, and transmitting a version of parliamentary politics that favoured government as the 'good guys' above the opposition.

This context-specific situation that emerged wedged me in a tight corner, somewhat of my own doing. On the one hand, Kalafi Moala's journalism code was relevant to my case as a field researcher. I agreed with Moala's sentiment; when culture contravenes work ethics, especially "truthfulness" on the job, culture is the culprit that gets binned (Moala, 2002, p. 237). 
I believe cultural demands in violation of universal principles of honesty, fairness, justice, balance, accountability and truthfulness are not worth being subjected to. (Moala, 2002, p. 237).

On the other hand, being directly descended from one of Tonga's original European/British trader families had cultural privilege, said no half-cast ever. But it is true, and if I am fixated on "truthfulness" as the benchmark principle for doing field research in Tonga, especially in the development industry, then I have to turn the incisive tool of critical reflection on myself and be conscientious about the politics of partiality (Ratuva, 2013).

Sitting at the table designated for Tongans at the Pacific Islands Media Association (PIMA) fundraiser dinner held in Auckland on November 2nd 2013, I listened to a conversation on who gets favour working in Tonga's development industry. From this discussion between my father Semi Pulu, a Tongan citizen from Kolonga, a rural farming village in Tonga's eastern district, and Melino Maka who is originally from Tatakamotonga, a village not far from dad's hometown, my indulged and pandered self-privilege got hit home to me. 


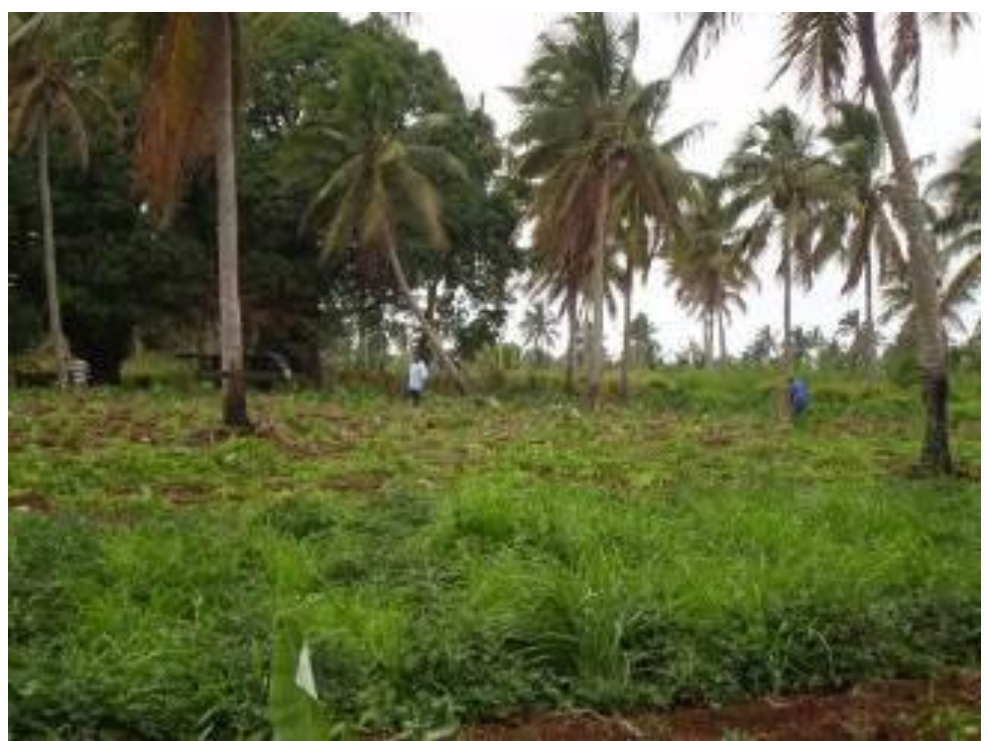

Local farmers at Vaini in Tonga's central district subsistence cropping on a small bush allotment to supplement their household income and food supply.

Semi commented that Melino's ability to think outside the box by steering away from old development habits where the state not small business owners control the economy, specifically for trade, is the reason the government bureaucracy does not engage his ideas on accelerating agricultural exports from Tonga to the New Zealand market.

Melino agreed, spelling out the obvious; that is, the fact he is Tongan and not Palangi (white/European) goes against him. The logic here is if he were Palangi by ethnicity, skin-colour, language, and culture, then the government would look approvingly at his work. However, being Tongan is a disadvantage in Tonga because an old-fashioned colonial mentality has persisted up to the present day, a debilitating mind-set in which Tongans are considered inferior, intellectually and in terms of business capability, to white people.

I piped up, adding that when Melino worked with me in Tonga as a field research assistant on a government report about the Nuku'alofa reconstruction project, the only reason 
why we got any measure of respect from Tongan bureaucrats was because they thought I was Palangi. Government employees knew I was half-cast European, not a full-blooded Tongan, and treated me differently, in many ways better than they would have if I was a local.

My father laughed not because it was by any means funny but because it was true; Tongan bureaucrats are renowned for treating their own people with haughtiness and contempt, while unashamedly greasing up to white people whom they believe are naturally superior, wealthier, smarter, and have better skin-colour than dark skin.

On Facebook I posted my disgruntlement at how the Tongan public service showed disdain for local people. It incensed me that my colleague Melino Maka was purposely ignored, his work in Tonga given a lower profile to mine because he is a full-blooded Tongan from a rural village with dark skin who speaks English as a second language in a heavy Tongan accent (Hyndman, 2000).

Melino had cultivated a couple of acres of chilli on his family plot in Tu'ipelehake, not far from Fua'amotu international airport. He sourced the buyer himself, an Auckland importer, and wanted to give the market to local farmers for income. The farmers were sceptical, however, about exporting in the economic downturn because the financial risk seemed daunting.

To complicate matters, the Government of Tonga were unwilling to offer stimulus grants to small-scale farmers but opted to provide short-term loans to middle-men who sold produce purchased from growers to overseas importers. How could a Tongan man living in Auckland who went home to farm and export not be taken seriously for his tenacity in taking business risk and putting his hard-earned money where his mouth is?

My Tongan/Samoan friend in Auckland Louina Fifita commented, "So disgustingly true Tina" (Fifita, 2013). Adding lived experience to the conversation, Richard Wolfgramm from Salt Lake City who immigrated to the United States from Vava'u in Tonga as a child wrote, "Ugggggh, wish that wasn't true but I've experienced it" (Wolfgramm, 2013).

The most telling commentary on white privilege came from 'Ofa Guttenbeil-Likiliki in Tonga who made it clear that she, for one, confronted and dealt with the politics of partiality in her non-government organisation workplace. 
I know what you mean which is why I treat any Palangi the same as I would treat any local when they come to my office. No special treatment whatsoever and then what always cracks me up is the fact that when I start to converse with Palangis who come to my office one of the first things they say is, "Oh, you speak very good English. Did you spend some time overseas?" And I say, "Well, you speak pretty good English yourself. Where did you come from?" which ALWAYS puts them off guard. (Guttenbeil-Likiliki, 2013b).

Stuck in my mind, replaying and troubling me was the racist overture and hypocrisy that in Tonga, an independent Pacific Island state since 1970 which brags about being a former protectorate of the British Empire that was not formerly colonised, coloured is inferior to white so Tongans are subservient to white people. Nothing seemed more unprogressively worrisome that after four decades of political independence, we had not reformed. The Kingdom of Tonga, still psychologically incarcerated as a protectorate of a redundant British Empire (Said, 1978, 2000).

\section{Horse and cart development}

It was the late Futa Helu's collection of essays published in 1999, Cultural Perspectives from the South Seas, which made reference to Tonga's development industry putting the cart before the horse. Writing at the end of the 20th century, he saw that entering the new millennium his South Seas islands had an imprint of modernity it kept duplicating across generations. Tonga was both traditional and modern, a living "paradox" was the term Helu used to depict the social and political contradictions that ordinary Tongans inherited as the Kingdom's legacy (Campbell, Coxon, and Helu, 2000). But tradition and modernity produced a confusing and convoluted mix of development ideas put into practice, or perhaps malpractice was a more suitable description. 


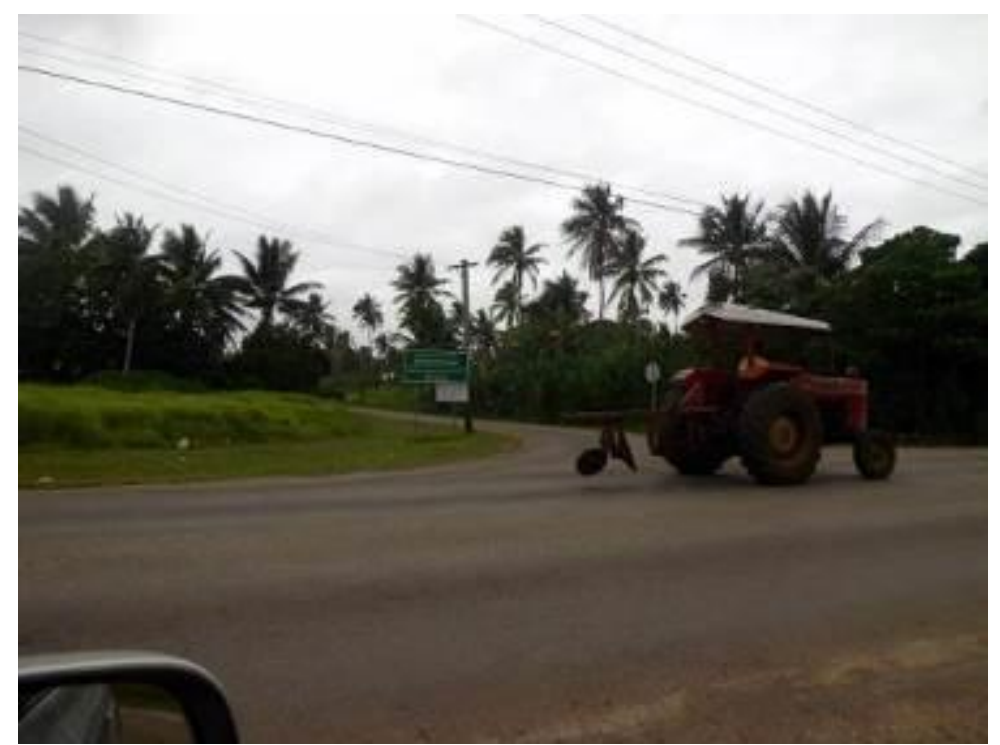

A local farmer at Vaini in Tonga's central district holds up motorists on the main road travelling from one bush allotment to another.

Helu recounted that attempts to advance Tonga by bringing it up-to-date and in line with Western democracies had flopped at fathoming how tradition, the authority of the monarchy and nobility, would be excluded from the development equation. Removing traditional power was not the desired option among the majority of people in Tonga as well as those living in New Zealand, Australia, and America. There had to be a Tongan way of doing development in the 21 st century. And paradoxically, it would have to recognise Tonga's 19th century origins of modern state and society, a hierarchical system of social organisation and political life where the monarch was constitutionally the head of state and the nobility were represented in a Westminster model of parliamentary democracy.

Putting Helu's 1990s cart before the horse analogy to the three discussants, I wanted to see if it resonated in their impressions of Tonga's 21 st century approach to doing development. It certainly did. Not only was the cart still placed before the horse but the horse was now accompanied by "a stable, a trainer, a stable-boy and a groomer," which did 
not move the cart forward because the various horses, personified as aid donors, were "pulling [the one cart] in different directions" (Hao'uli, 2013).

Sefita Hao'uli was quick off the mark. He was Futa Helu's nephew and could recall his uncle's scholarly work and Atenisi (Athens) style philosophy. ${ }^{3}$ Sefita traced the "horse and cart" story to Atenisi tertiary institute in the 1960 s when he was a young man, the institute that Helu founded and directed for over four decades. The difference in the present day was marked by the proliferation of the aid industry where competing donors from overseas countries rivalled for first place. Occupying first place called for manoeuvring Tonga into having the strongest economic dependency on an aid donor's country over all others with little regard for whether donations, grants, bank loans, and the monitoring system that came with it were useful, practical, relevant, or actually worked at improving Tonga's developing country predicament (Asian Development Bank, 2013).

The best horse and cart story we used to enjoy around Atenisi (and was never told when Samoans were around) was when aid funds were coming into the country in the 60s to help pull the cart. Everyone agreed that was what was needed and two years later when the donors turned up to see what had happened, they found the cart still in the same spot and of course the horse was missing. They ate it. Now, they not only bring the horse but they also bring a stable, a horse trainer, a stable-boy and a groomer to make sure that the horse isn't eaten. They put the harness on and pull only to find the cart's not moving much at all. On close scrutiny, Tonga has asked for several horses and they're all hooked up to the same cart and pulling in different directions. Tonga asks for $\mathrm{NZ}$ aid for tourism. It ousted Chatham Air and brings in an aircraft to scare the tourists. Now, China and NZ will be arguing on the merit of their respective horses and have forgotten about the cart. (Hao'uli, 2013).

Kalafi Moala questioned the cart before the horse scenario. After four decades of being made into a passive recipient of an international development industry that prioritised aid donor interests over local people's livelihoods in a country that struggled to get the majority of citizens above the poverty line, 
he was doubtful the contents of the cart were of any use. Alleviating poverty was the urgent priority in a small island developing state. Therefore, "eating the horse and dismantling the cart to build an outhouse may be the most appropriate use" for the existing system, he thought (Moala, 2013b).

I am interested to find out what's in the cart, and why it takes several horses to pull one cart. We should check because it may be empty, and the cart before the horse or the horse pulling the cart arrangement may be totally irrelevant if the cart does not carry something for Tonga! In fact, eating the horse and dismantling the cart to build an outhouse may be the most appropriate use. (Moala, 2013b).

Sefita signalled at how problematic it was to engineer a coordinated approach to national development with conflicting aid donors in competition for economic control. If one developed country such as New Zealand and its Western allies, Australia and the USA, dominated Tonga's purchase of imported goods as well as the export trade market, then their influence over politics and the system of democratic government Tonga took up followed suit (Coutts, 2013). Likening systematic development to a "domino effect," a mechanical result in which small change caused by individual projects across various sectors triggered broader change to the national system was Sefita's concern. The difficulty was getting the "dominoes" or the development projects lined up in order to correspond with each other in meeting national policy objectives and achieving a comparable "effect" (Hao'uli, 2013).

And while the idiomatic horse and cart is easy to understand, in some circumstances, you may want to look at the domino effect as being more appropriate where the dominoes either fail to fall or where the dominoes are at different spots along the chain and begin to fall towards each other rather than the intended direction. (Hao'uli, 2013).

"The moa'uli phenomenon" as Sefita Hao'uli put it was raised in conversation by Kalafi Moala to describe the significant role of the middle man, the intermediary in Tonga's development industry (Hao'uli, 2013). Literally translated into English as black chicken or black fowl, the moa'uli in 
contemporary Tonga was a social referent to a person whose development work involved mediating, advising, and managing relationships on behalf of the power broker, the person at the top with the authority. ${ }^{4}$ Moa'uli could be a supplementary term for a consultant, an advisor, or a project manager. Kalafi's point was that "we've always had a tradition of matapule [orators, speakers] and the role of an orator is important to Tongan society" (Moala, 2013a).

Sefita traced the origin meaning of moa'uli illustrating the very term itself had undergone a makeover and that language is subject to change. In this context, language is not stagnant but rather, reshaped by the environment it inhabits and how it is used to explain lived realities.

The moa'uli phenomenon: Essentially, a person acting as an intermediary in winning the affections or consent of a girl or woman that one wishes to marry. Moa'uli is the verb. It is a role which is usually, but not always, performed by a woman because courtship in a small tight community meant that a suitor would not want to declare his hand openly and raise the suspicion of his rivals, or in cases where he is seen by the girl's family as either unsuited or undesirable. The woman - moa'uli - provides the necessary cover in what could be seen as a covert operation. It could also be seen as an art because in its highest form, no one is to know what goes on. (Hao'uli, 2013).

Whether "the moa'uli phenomenon" functions in its original meaning as a marriage match-maker or by its contemporary form in Tonga's development industry as a consultant mediating between the aid donor and the local people, one detail needed unpicking. Criticism against consultants and middle-men was becoming increasingly vocal and volatile in Tonga. The argument was that this socially mobile group were costly, unnecessary, clandestine opportunists collecting secretive salaries from an industry bankrolled by taxpayer dollars; an industry where funds could be put to better use for carrying out sustaining, and training local Tongans to manage development projects on the ground.

Had the moa'uli done its dash? Would the modern day moa'uli be subject to restructuring and due to budgetary constraints and public sector efficiency priorities made redundant? Then again as Kalafi mentioned, would the 
importance of "tradition" and preserving "the role of an orator to Tongan society" remain intact throughout the 21 st century development industry? (Moala, 2013a).

\section{Is there a Tongan way to doing development research?}

At the twentieth meeting of the Pacific heads of education held in Nuku'alofa in October of 2013, Tonga's Minister for Education Dr 'Ana Taufe'ulungaki made a candid and cutting observation. In her view, it was the educators' "poor attitude and lack of professional commitment" that failed the system and students not the "limited funding or ill-trained human resources" (Television Tonga News, 2013g). Taufe'ulungaki's stand was directly at odds with the climate change industry headed by Lord Ma'afu, the Minister for Lands and Environment. Ma'afu stated outright that limited funds sourced from international donor organisations and investors hampered development, restrained project planning and implementation, and in crisis situations of natural disaster narrowed down options for national preparedness and recovery (Television Tonga News, 2013a, 2013b, 2013c).

The biggest challenge that Tonga is facing today in education is not limited funding or ill-trained human resources but poor attitude and lack of professional commitment. If we can raise teachers and staff morale and ethical behaviour to add to these initiatives, I believe we could make real differences in educational outcomes for students in Tonga. The questions that the donors, development partners, parents, communities, the Tonga government and the Ministry of Education are all asking are have we really moved forward? Do we have concrete evidence that we have made significant progress? Have we significantly improved in terms of student achievements, especially in basic literacy and numeracy? The honest answer is despite all investments and the various initiatives, programmes and interventions, and despite all assistance and support we have received from Australia, New Zealand, Japan, China, the World Bank, and regional organisations and institutions such as the Institute of Education, the University of the South Pacific, SPPA, $S P C$, and the Forum, we still cannot give an unequivocal yes. ('Ana Taufe'ulungaki cited in Television Tonga News, 2013g). 
Why was Tonga's public education system different? Or was the Minister, herself a former tertiary educator of the University of the South Pacific, taking a critical view of change management in a sector integral to growing the younger generation of Tonga's workforce; a workforce that not only needed jobs but a high-level of skills and leadership to cope with a more complex set of challenges in an integrated region much different to the living environments which young people's parents and grandparents had lived through.

One factor shone like a light: Taufe'ulungaki was talking about adjusting intergenerational attitudes toward education practice in the classroom, noting the buck starts and stops in Tonga (Manu'a, 2013). What she implied is that unless educators can competently prepare students for resolving worldly problems in a small island developing state, the education system had little relevance for advancing new generations of workers, thinkers, and leaders.

The fact that Taufe'ulungaki is a full-blooded Tongan woman speaking out on long-running education disparities compounded by the "poor attitude and lack of professional commitment" of educators exemplifies the struggle of women's leadership in Tonga. It is one thing to speak up in public and risk going against the grain, but it is another to actually be heard, acknowledged, and granted social license to make change happen. The latter was the treacherous path to tread; that is, how to get the authority in charge, which in this case was the government, to agree that transforming Tonga's educators employed in the primary and secondary school system was high priority work.

In that same month of October 2013, a group of predominantly women artists and craftspeople from the Kingdom of Tonga visited Auckland and Wellington on an exchange funded by New Zealand Aid in which they showcased their artworks and conducted workshop demonstrations to the New Zealand public. Kolokesa Mahina-Tuai, an art historian and Tongan New Zealander spoke to Radio New Zealand's Pacific news service, explaining what she saw were the baseline principles of creating "Tongan art" (Radio New Zealand International, 2013).

Mahina-Tuai says the group's art is unique to Tonga and the artists present an alternative to New Zealand ideas of art. She says Tongan art is a 
combination of function and aesthetic and is an integral part of daily Tongan life. (Kolokesa Mahina-Tuai cited in Radio New Zealand International, 2013).

"A combination of function and aesthetic [as] an integral part of daily Tongan life" were Mahina-Tuai's words that kept repeating in my head. And I wondered in the transience of a field researcher's life where I shift from one view to another, often weaving multiple perspectives to create a mosaic of public opinion, how this applied to doing development research in a Tongan way. If reflecting the "function and aesthetic [of] daily Tongan life" were the core components of research competency in Tonga's development industry, then the greater effort was realising the second part of the arrangement.

What was a Tongan development aesthetic? Development projects borrowed Western jargon to validate the Western logic that economic growth meant progress for poor developing countries. But including an artistic feel, a creative texture, an innovative consistency to how development was done did not enter political conversations around new leadership, modernisation, democratisation, and regional trade integration.

Again in the month of October 2013, 'Ofa GuttenbeilLikiliki commented on my Facebook page. She had become my social conscience, performing the task of reminding me that the presence of women at all levels of public dialogue mattered to Tongan development, and without women's participation a lop-sided system of disproportion and inequality prevailed.

Tina, you need to talk to women as well in your upcoming book. You have three men named there. I hope you have some dialogues with Tongan women. (Guttenbeil-Likiliki, 2013c).

'Ofa Guttenbeil-Likiliki was right. I acknowledge that and will get to it because it is integral to include Tongan women in development dialogues if there is genuine concern for equity and accountability in the country's decision-making processes. But for the time being, while wading through a sea of ideas that the "three men named there" have brought to conversations as well as selecting their discussion points for 
publication, I will close this first essay of four with Kalafi Moala's thoughts (Guttenbeil-Likiliki, 2013c).

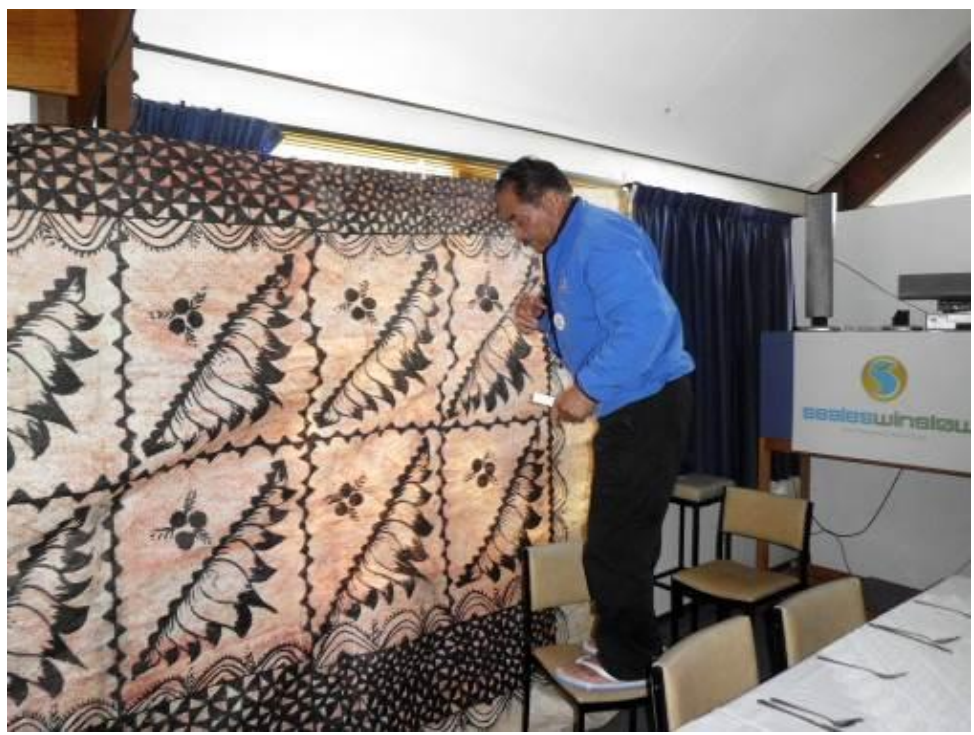

Teena Brown Pulu's father, Semi Pulu, who migrated to Dunedin in 1966 from Kolonga in Tonga hanging a ngatu (bark cloth) to decorate the hall for the Tongan early settlers reunion at Dunedin Rugby Club in November 2013.

Not all Tongan men from the older generation speak and behave with a patriarchal tone and tenor hostile to younger Tongan women born overseas of mixed-blood who are outspoken, strong-willed, and upfront with their opinions. I know this is true. My father is a 66 year old full-blooded Tongan migrant to New Zealand from a rural village. He would not have assisted my half-cast mother born in Tonga with British citizenship and socialised to speak prim and proper English to raise a daughter like me if he were culturally conservative, narrow-minded, and resistant to social change.

On that note, Kalafi's sentiments show that change is not only possible but is the lived reality we contend with across generations. And in saying this, those who possess greater aptitude at adapting to change endure. While those incapable 
of adjusting find it difficult to cope with the trials and tests of our current times.

I believe that the Tongans of the 21 century who have the capability and experience of operating in the complex world of multiculturalism and geopolitical realism are the ones who will help to navigate our national kalia to fulfil our destiny. And our people in the diaspora seem to be the best equipped, especially those who are humble enough to maintain their homeland links. Thank you Teena for keeping these relevant issues before us. (Moala, 2013c). 


\section{References}

Alatas, S. H. (2012). The Myth of the Lazy Native: A Study of the Image of the Malays, Filipinos and Javanese from the 16 to the 20 Century and its Function in the Ideology of Capitalism. New York, USA: Routledge.

Alefosio, M. (2013). Black Polynesia: Marina Alefosio at TEDx Auckland. TEDx Talks, Auckland, New Zealand, September 3. Retrieved from

https://www.youtube.com/watch?v=0TF6En-qYE4

Asian Development Bank. (2013). Asian Development Outlook 2013 Update: Governance and Public Service Delivery. Mandaluyong City, Manila, Philippines: Asian Development Bank.

Brenneis, D. and Myers, F. (1984). Dangerous Words: Language and Politics in the Pacific. New York, USA: New York University Press.

Brown Pulu, T. (2013a). This Lazy Native's Quitting the Daytime Job. Going Home to the Village. Yeah Right. In Pacific Identities and Wellbeing: Cross-Cultural Perspectives, edited by M. Agee, T. McIntosh, P. Culbertson, and C. Makasiale. Dunedin, New Zealand: Otago University Press, Pp. 84-102.

Brown Pulu, T. (2013b). Report Went to Court: Tonga's Parliamentary Report on the Nuku'alofa Reconstruction. The Kaharoa: The $e$ Journal on Indigenous Pacific Issues, 6 (1): 184-216.

Clifford, J. (1988). The Predicament of Culture: Twentieth Century Ethnography, Literature and Art. Cambridge, Massachusetts, USA: Harvard University Press.

Coutts, G. (2013). Independent AusAID program officially ends today. Radio Australia: Pacific Beat: Australian Broadcasting Corporation, Melbourne, Australia, November 1. Retrieved from

http://www.radioaustralia.net.au/international/radio/program/pacifi c-beat/independent-ausaid-program-officially-endstoday/1213192

Hyndman, D. (2000). Dominant Discourses of Power Relations and the Melanesian Other: Interpreting the Eroticized, Effeminizing Gaze in National Geographic. CulturalAnalysis, 1: 15-33.

Facebook 1. (2013). Facebook Post to Teena Brown Pulu, Auckland, New Zealand, July 22.

Fifita, L. (2013). Facebook Post to Teena Brown Pulu, Auckland, New Zealand, November 8.

Fordham, S. (1996). Blacked Out: Dilemmas of Race, Identity, and Success at Capital High. Chicago, USA: University of Chicago Press.

Foucault, M. (1982). The Subject and Power. Critical Inquiry, 8 (4): 777-795.

Foucault, M. (1972). The Archaeology of Knowledge and the Discourse on Language, translated from the French by A. M. Sheridan Smith. New York, USA: Pantheon Books.

Foucault, M. (1970). The Order of Things. London, United Kingdom: Tavistock Publications. 
Gramsci, A. (2005). Selections from the Prison Notebooks. London, United Kingdom: Lawrence \& Wishart Limited.

Guttenbeil-Likiliki, 'O. (2013a). Facebook correspondence to Teena Brown Pulu. Nuku'alofa, Tonga, September 30.

Guttenbeil-Likiliki, 'O. (2013b). Facebook correspondence to Teena Brown Pulu. Nuku'alofa, Tonga, November 8.

Guttenbeil-Likiliki, 'O. (2013c). Facebook correspondence to Teena Brown Pulu. Nuku'alofa, Tonga, October 31.

Hall, E. T. (1989). Beyond Culture. New York, USA: Anchor Books, A Division of Random House Incorporated.

Hao'uli, S. (2013a). Discussion 1: Sefita Hao'uli, Kalafi Moala, and Melino Maka. Auckland, New Zealand, September 27.

Hao'uli, S. (2013b). Email correspondence to Teena Brown Pulu, Kalafi Moala and Melino Maka. Auckland, New Zealand, September 28.

Hau'ofa, E. (1994a). Tales of the Tikongs. Honolulu, Hawai'i: University of Hawai'i Press.

Hau'ofa, E. (1994b). Our Sea of Islands. The Contemporary Pacific, 6 (1): 141-161.

Hau'ofa, E. (2000). Epilogue: Pasts to Remember. In Remembrance of Pacific Pasts: An Invitation to Remake History, edited by R. Borofsky. Honolulu, Hawai'i: University of Hawai'i Press.

Hau'ofa, E. (2008). The New South Pacific Society: Integration and Independence. In We are the Ocean: Selected Works by Epeli Hau'ofa, foreword by Geoffrey White. Honolulu, Hawai'i: University of Hawai'i Press, Pp. 11-26.

Helu, 'I. F. (1999). Critical Essays: Cultural Perspectives from the South Seas. Canberra, Australia: Australian National University, Journal of Pacific History.

James, K. (2003). Is There a Tongan Middle Class? Hierarchy and Protest in Contemporary Tonga. The Contemporary Pacific, 15 (2): 309-336.

Kaplan, A. and Haenlein, M. (2010). Users of the world, unite! The challenges and opportunities of Social Media. Business Horizons, 53 (1): 59-68.

King, M. L. (1986). I Have A Dream: Writings and Speeches that Changed the World, edited by J. M. Washington. New York, USA: Harper Collins Publishers.

Maka, M. (2013). Discussion 1: Sefita Hao'uli, Kalafi Moala, and Melino Maka. Auckland, New Zealand, September 27.

Manu'a, R. (2013). Our language, our responsibility, Head of State Tui Atua reminds. Samoa Observer, Apia, Samoa, October 25. Retrieved from

http://www.samoaobserver.ws/education/7673-our-language-ourresponsibility-head-of-state-tui-atua-reminds

Marcus, G. E. (1980). Role Distance in Conversations between Tongan Nobles and their People. The Journal of the Polynesian Society, 89 (4): 435-453. 
Marsh, S. T. (2009). Fast Talking PI. Auckland, New Zealand: Auckland University Press.

Moala, K. (2013a). Discussion 1: Sefita Hao'uli, Kalafi Moala, and Melino Maka. Auckland, New Zealand, September 27.

Moala, K. (2013b). Email correspondence to Teena Brown Pulu, Sefita Hao'uli and Melino Maka. Auckland, New Zealand, September 28.

Moala, K. (2013c). Facebook comment to Teena Brown Pulu. Auckland, New Zealand, October 30.

Moala, K. (2002). Island Kingdom Strikes Back: The Story of an Independent Island Newspaper - Taimi O Tonga. Auckland, New Zealand: Pacmedia Publishers Limited.

Morton Lee, H. (2003). Tongans Overseas: Between Two Shores. Honolulu, USA: University of Hawai'i Press.

Pacific Media Assistance Scheme. (2013a). Regional State of Media and Communication Report 2013. Canberra, Australia: Australian Aid and Australian Broadcasting Corporation.

Pacific Media Assistance Scheme. (2013b). Tonga State of Media and Communication Report 2013. Canberra, Australia: Australian Aid and Australian Broadcasting Corporation.

Quan-Haase, A. and Young, A. (2010). Use and Gratifications of Social Media: A Comparison of Facebook and Instant Messaging. Bulleting of Science Technology Society, 30 (5): 350-361.

Radio New Zealand International. (2013). Kolokesa Mahina-Tuai cited in Master artists from Tonga share their knowledge with New Zealand. Radio New Zealand International, Auckland, New Zealand, October 24. Retrieved from

http: / / www.rnzi.com/pages / news.php?op=read\&id=80088

Ratuva, S. (2013). Politics of Preferential Development: Trans-global study of affirmative action and ethnic conflict in Fiji, Malaysia and South Africa. Canberra, Australia: Australian National University E Press.

Said, E. W. (1978). Orientalism. London, United Kingdom: Routledge \& Kegan Paul.

Said, E. W. (2000). A View from Afar (Middle East): An Interview with Edward Said. In Remembrance of Pacific Pasts: An Invitation to Remake History, edited by R. Borofsky. Honolulu, Hawai'i: University of Hawai'i Press.

Taylor, G. (2013). The Power of Words: Grace Taylor at TEDx Auckland. TEDx Talks, YouTube upload, Auckland, New Zealand, September 3. Retrieved from

https://www.youtube.com/watch?v=LivPMiYik9g

Taylor, G. (2011). Being Afakasi. YouTube upload, Auckland, New Zealand, June 20. Retrieved from

https://www.youtube.com/watch?v=ruizDW9Lg0Q

Teaiwa, T. (1995). Scholarship from a Lazy Native. Work in Flux, Sydney University of Technology: 58-72.

TED. (2013). TED: Ideas worth spreading: About TEDx. New York, USA, Retrieved October 30.

http://www.ted.com/pages/about_tedx 
TEDx Auckland. (2013). TEDx Auckland: $\mathrm{x}=$ independently organised TED event. Auckland, New Zealand, Retrieved October 30.

http://tedxauckland.com/

Television Tonga News. (2013a). Lord Ma'afu cited in Television Tonga News in English. Tonga Broadcasting Commission, Nuku'alofa, Tonga, September 27. Retrieved from

https: / / www.youtube.com $/$ watch?v $=$ FpExjlk28tA\&feature $=c 4-$ overview\&list=UUJsR-wS1oz5i-0hNUsWU_9w

Television Tonga News. (2013b). Lord Ma'afu cited in Tonga This Week in English. Tonga Broadcasting Commission, Nuku'alofa, Tonga, September 29. Retrieved from

https: / / www.youtube.com / watch?v=fu62OIwBeKU\&feature $=$ c4overview\&list=UUJsR-wS1oz5i-OhNUsWU_9w

Television Tonga News. (2013c). Lord Ma'afu cited in Television Tonga News in Tongan. Tonga Broadcasting Commission, Nuku'alofa, Tonga, October 1. Retrieved from

https: / / www.youtube.com/watch?v=UFmeyjxaf9o\&feature $=c 4-$ overview\&list=UUJsR-wS1oz5i-OhNUsWU_9w

Television Tonga News. (2013d). Friendly Islands Shipping Agency cited in Television Tonga News in English. Tonga Broadcasting Commission, Nuku'alofa, Tonga, October $7 . \quad$ Retrieved from

https: / / www.youtube.com/watch?v=UFpli7gwVJY\&feature=c4overview\&list=UUJsR-wS1oz5i-OhNUsWU_9w

Television Tonga News. (2013e). Lord Ma'afu cited in Television Tonga News in Tongan. Tonga Broadcasting Commission, Nuku'alofa, Tonga, October 8. Retrieved from

https: / / www.youtube.com/watch?v=OK-8-PqbwqU\&feature=c4overview\&list=UUJsR-wS1oz5i-0hNUsWU 9w

Television Tonga News. (2013f). Peter Lange of MG Marketing NZ cited in Television Tonga News in English. Tonga Broadcasting Commission, Nuku'alofa, Tonga, October 9. Retrieved from

https: / / www.youtube.com / watch?v=cIoPbrbHQhs\&feature=c4overview\&list=UUJsR-wS1oz5i-0hNUsWU_9w

Television Tonga News. (2013g). 'Ana Taufe'ulungake cited in Television Tonga News in English. Tonga Broadcasting Commission, Nuku'alofa, Tonga, October 23. Retrieved from

https: / / www.youtube.com/watch?v=7e7TeMTZNFk\&feature=c4overview\&list=UUJsR-wS1oz5i-OhNUsWU_9w

Viner, K. (2013). The rise of the reader: journalism in the age of the open web. The Guardian, London, United Kingdom, October 9. Retrieved from

http://www.theguardian.com/commentisfree/2013/oct/09/the-riseof-the-reader-katharine-viner-an-smith-lecture

Wolfgramm, L. (2013). Facebook Post to Teena Brown Pulu, Salt Lake City, Utah, USA, November 8. 


\section{Glossary of Tongan, Samoan, and Maori terms}

Afakasi

Atenisi

Fie' vale loi

Matapule

Moa'uli

Palangi

Pakeha
Samoan transliteration for half-cast with the Tongan transliteration being hafekasi.

Tongan transliteration for Athens, the tertiary institute established by Futa Helu in Tonga.

A situation where a person pretends they did not know of the relationship tensions between certain people causing conflict. In context, the person acts dumb, pretending they had no idea to avoid having to take sides.

An orator, a designated speaker usually with a title, whose role is to make formal speeches at gatherings on behalf of an important person of status and power, a traditional leader such as a noble, as well as a group of people associated with an important person.

Literally translated into English as black chicken or black fowl. As Sefita Hao'uli explained in email correspondence: "It is essentially a person acting as an intermediary in winning the affections or consent of a girl or woman that one wishes to marry. Moa 'uli is the verb. It is a role." (Hao'uli, 2013a).

White/European

Maori for white/European

\section{Photographs}

Seifta Hao'uli, Photograph by Pacific Media Centre, Auckland, 2009.

Kalafi Moala, Photograph by Café Pacific, Auckland, 2009.

Melino Maka, Photograph by Melino Maka, Auckland, 2013.

Tales of the Tikongs, Photograph by Pacific Island Books, Colorado, 2013.

Tongan ngatu, Photograph by Teena Brown Pulu, Auckland, 2013.

Marina Alefosio, Photograph by TEDx Auckland, Auckland, 2013.

Vaini farmers, Photograph by Teena Brown Pulu, Tonga, 2013.

Vaini farmer, Photograph by Teena Brown Pulu, Tonga, 2013.

Semi Pulu, Photograph by Teena Brown Pulu, Dunedin, 2013.

\section{Endnotes}

1 Hao'uli, S. (2013c). Email Correspondence to Teena Brown Pulu. Auckland, New Zealand, November 10. 
A couple of lingering thoughts. A need to explain the complexity of the Tongan male to male relationship - and why that can often be a hindrance in getting things done, and with 'Ofa Guttenbeil's wish for inclusion of women ringing in my ear, a more explicit appreciation of how Tongan men and women behave towards each other in diaspora and what changes when they are back home.

\section{Sefita Hao'uli}

Sefita emailed me editing comments on the original manuscript. Working in printed media and television and radio broadcasting for over thirty years, Pacific journalists acknowledged him as a founding commentator on Pacific Island affairs in New Zealand and the region. As an observer and critic who pulled no punches so to speak, he was renowned for his honest handling of contentious political issues.

His insights point to the "relationship complexity" that more often than not take hold between Tongan men. He also questions how geographic location, e.g. New Zealand or Tonga, is a distinctive factor shaping the way that communication between Tongan men and women is conducted. What differences become apparent in the mode and method by which Tongan men and women communicate in Tonga compared to New Zealand?

If anything, conservative borders and boundaries delineating genderspecific roles, particularly notions of polite, indirect, and non-critical conversation between Tongan men and women, are heightened in Tonga. This is primarily because Tonga is the ancestral homeland from which gendered and cultural communication originates. But under what circumstances is it possible to breach boundaries?

In my case, the fact I am identified in Tonga's public life as a half-cast woman descended from an original European/British trader family resettled in Tonga since the first quarter of the 20th century permits me to speak directly with Tongan men working in the government bureaucracy. I can ask forthright questions and request information with a certain measure of politeness and well spoken English simply because this is considered to be Palangi (European/white) speech and behaviour, the type of communication and manner that my kind are associated with. There is privilege in being socially permitted to behave like this. Whereas Tongan women identified as full-blooded Tongans might not be afforded the same social freedom, especially when communicating with Tongan men who are state officials and bureaucrats regarded as possessing government authority over ordinary people.

In terms of the "relationship complexity" imbued in communication between Tongan men, I can only speak to this as an outsider, as a woman who is not looked upon in conservative circles as racially and culturally pure because of my mixed-ethnic heritage. To be ruefully blunt, communication between full-blooded Tongan men whether it is 
conducted in Tonga or New Zealand can be fraught with tension and rivalry, especially if the men are not kinfolk by blood.

One reason I believe to be significant here is that Tongan men jostle and elbow each other in dialogical exchange for a higher-ranking position of social status. Status is demarcated by traditional identity signposts such as who is related to whom of importance, and where in Tonga one descends from. The Nuku'alofa town area holds court as a central place in Tonga's modern history and as the country's central business district. I have never quite fathomed why Nuku'alofa is held in high regard over rural villages with farm land because Tonga's capital is overcrowded and dirty. Town suffers from waste management, water, and sanitary problems, and has squatter settlements flanking its borders. In addition, Nuku'alofa is predominantly made up of migrants from the outer islands with the majority of the urban population having no land entitlement on Tongatapu.

In saying this, I am aware of my own positional bias in having a Tongan father from a rural village in the eastern district of Tongatapu who has an 'api and bush allotment. In my view, land scarcity and the fact that many Tongan men do not have land entitlement is a bone of contention that underlies male insecurity and identity friction.

This endnote does not provide an in depth account of how communication is conducted between Tongan men, and Tongan men and women, across a range of circumstances and geographic locations. Rather, this is a brief assemblage of my own thoughts in response to Sefita's inquiry. A topic of this kind could produce a separate essay, or quite possibly a series of articles.

2 See TEDx Auckland link: http://tedxauckland.com/ See TED link on TEDx: http://www.ted.com/pages/about_tedx

TEDx Auckland is an "independently organised TED event" (TEDx Auckland, 2013). TED is a US company based in New York with global reach, and the TED anachronism stands for technology, entertainment, and design. The TED brand is "ideas worth spreading" where the TEDx programme, a branch of TED, is specifically "designed to give communities, organizations and individuals the opportunity to stimulate dialogue through TED-like experiences at the local level" (TED, 2013).

See link to the trailer for Tongan Ark, an independent film by Public Films, directed by Paul Janman: https: / / www.youtube.com/watch?v=TD7HfPcK5kQ

Atenisi is the Tongan transliteration for Athens, the name of the tertiary institute that the late Futa Helu established in Tonga. Over four decades as Atenisi's director and founding professor, Helu 
developed a style of Tongan philosophy and history that fused classical Greek philosophy with oral recollections of ancient Tongan society before the advent of Christianity and the 1875 constitution. Atenisi's directorship is now in the hands of Helu's daughter.

Hao'uli, S. (2013d). Email Correspondence to Teena Brown Pulu. Auckland, New Zealand, November 10.

I believe that [moa'uli] requires a more accurate context and that black chicken doesn't quite capture it. I think that "fowl" would be more appropriate. For example, it is a mature bird of either gender but I wonder whether "uli in this context could also mean "dirty" or "dark" rather than black. A "fowl operating in the dark" could explain this better than the more literal "black chook or chicken."

\section{Sefita Hao'uli}

Sefita commented that a literal English translation of moa'uli as black chicken did not portray the metaphoric inference of the term without greater context given to why, in certain circumstances, the role and activity of a moa'uli could be interpreted as "dirty, dark" foul (word play on fowl), covert, or undercover.

Once again, the linguistic value and imbedded meanings attributed to the social referent moa'uli could be a topic for a separate article. 